\title{
ICONOMIC CHALLENGES IN EARLY MODERN AGES AND DIFFERENT RESPONSES OF EUROPEAN MARGINS. COMPARATIVE CONSIDERATIONS BASED ON HISTORIOGRAPHY: THE CASES OF POLISH-LITHUANIAN COMMONWEALTH AND MOLDAVIAN PRINCIPALITY
}

\author{
Nerijus Babinskas \\ Vilnius University, E-mail: nerijus.babinskas@if.vu.lt
}

\section{Acknowledgments}

This paper has been presented at the Third International Conference on Nordic and Baltic Studies in Romania: European Networks: the Balkans, Scandinavia and the Baltic World in a Time of Crisis hosted by the Romanian Association for Baltic and Nordic Studies and Valahia University of Târgoviste, and sponsored by the Romanian National Research Council, May 25-27, 2012.

\begin{abstract}
:
This paper desires to draw attention to some stereotypes that simplify perception of historical reality, but nevertheless still prevail in historiography. There is a very common statement about the so-called second edition of serfdom (based on manorial-serve economy) that spread all around the Eastern Europe region in the $16^{\text {th }}$ century. This turn in social development is usually explained as determined by internal as well as external factors. If the problem considered is placed under Marxist views, one can distinguish two extreme poles: traditional Marxism and world-system approach. Supporters of traditional Marxism emphasize internal factors while adherents of world-system attitude accentuate external factors. The author argues that the regime of serfdom established in Moldova until 1600 is not consistent with the classic model. In this case, one can talk only about another type of second serfdom that differs from that of Eastern Germany as well as from Central Europe. It would be also a gross simplification to claim that second serfdom phenomenon was caused exclusively by external reasons. Internal causes are not less but probably
\end{abstract}


even more decisive, at least in some cases. As the work of Darius Žiemelis has showed recently, statements of world-system approach toward certain societies are worth of critical reconsideration.

\section{Rezumat:}

Studiul de față are intenția să atragă atenția asupra unor stereotipuri care simplifică percepția asupra realității istorice, dar, cu toate acestea, încă predomină $\hat{\imath}$ istoriografie. Există o afirmație foarte obişnuită despre aşanumita a doua iobăgie (bazată pe raportul economic boier-țăran dependent), care s-a răspândit în întreaga aşa-numită regiune a Europei de Est în secolul al XVI-lea. Cauzele acestei transformări a dezvoltării sociale sunt, de obicei, explicate atât prin factori interni cât şi externi. Dacă am ancora problema mentionată în cadrul explicatiei marxiste, se pot distinge două extreme: marxismul tradițional şi abordarea sistemului mondial. Susținătorii marxismului traditional subliniază factorii interni, în timp ce adepții teoriei sistemului mondial accentuează factorii externi. Autorul susține că regimul de iobăgie stabilit în Moldova până în anul 1600 nu corespunde modelului clasic. In acest caz se poate vorbi doar despre un alt tip de A Doua Iobăgie, care diferă de cea din Germania de Est, precum şi de cea din Europa Centrală. Ar fi, de asemenea, o simplificare evidentă, să pretindem că fenomenul celea de-a Doua Iobăgii a fost cauzat doar de motive externe. Cauzele interne nu sunt mai mici, ci, probabil, chiar mai decisive, cel puțin, în unele cazuri. Aşa cum a arătat recent lucrarea lui Darius Žiemelis, paradigma sistemului mondial față de anumite societăți merită o reconsiderare critică.

Key words: second serfdom, manorial-serf system (Folwark), corvée (labour rent), international trade, Marxism.

\section{Introductory considerations}

First of all, I would like emphasize that the main topic of this paper would be the phenomenon of the second serfdom from comparative perspective. Since, as we know, the concept of the second serfdom is introduced by Friedrich Engels, I would like to confine myself to deal with this issue only from the Marxist point of view.

Let us start with some stereotypes.

\section{Stereotype: second serfdom}

During the 1960s Fernand Braudel, the famous French historian, wrote "Although this reaction was detectable all over Europe, it was particularly tragic in Central and Eastern Europe - in Germany beyond 
the Elbe, in Poland, Bohemia and Austria, and even in the Balkans and in Muscovy. As the sixteenth century ended, there was established throughout these regions (some of them still barbarian) what historians more and more tend to call 'the second serfdom "'

Let us consider the statement of $\mathrm{F}$. Braudel with reference to contemporary historians. According to contemporary authors of a rather comprehensive and new "History of Eastern Europe"(second edition published in 2007), Robert Bideleux and Ian Jeffries, "a fundamental EastWest socio-economic divergence began within Europe" 2 about the end of the fifteenth century. It was exactly the so called 'second serfdom' in Eastern Europe which had caused the large estates cultivated by forced labour to become the typical Eastern partner in the East-West division of labour that developed ${ }^{3}$. What is important to add, R. Bideleux's and I. Jeffries's opinion is based also on the classic text written by a Hungarian historian Jenö Szücs in 1980s "The Three Historical Regions of Europe“ in which he wrote: "growing demand from the urbanized West for agricultural products, causing the large estates cultivated by forced labour to become the typical Eastern partner in the East-West division of labour that developed"4.

Concerning the causes of the second serfdom F. Braudel's statement is even more outspoken: "the lord was the head of the farm, the entrepreneur, the wheat merchant. To meet the growing demand for grain, he forced his peasants to increase the amount of bond-service they owed him" 5 .

Do those statements correspond more or less to the contemporary state of knowledge of this issue available in historiography?

To tell the truth, R. Bideleux and I. Jeffries do not approach Eastern Europe as an homogenous region - they make the following statement: "Indeed, this so-called 'second serfdom' became much more widely

\footnotetext{
1 F. Braudel, A History of Civilizations (Penguin Books, 1993), 318; compare original French text: F. Braudel, Grammaire des civilisations (Paris: Flammarion, 1993), 434.

2 R. Bideleux and I. Jeffries, A History of Eastern Europe. Crisis and Change. Second Edition. (London, New York: Routledge, 2007), 162.

${ }^{3}$ Ibid., 162; Bideleux and Jeffries statement is based on J. Szücs text "The three Historical Regions of Europe", Acta Historica Academiae Scientiarum Hungaricae, vol. 29, 2-4 (1983): 159160.

4 Szücs, 160.

${ }^{5}$ Braudel, A History of Civilizations, 318.
} 
prevalent in East Central Europe than in the Balkans, where it was largely confined to Romania, Croatia and Bosnia-Herzegovina"6.

So, if we believe R. Bideleux and I. Jeffries and keep their statement in mind, both (or rather all three) cases we have chosen for our comparison are worth of that procedure since in both cases "second serfdom" should be prevalent.

In order to deal with the phenomenon of the second serfdom in proper, precise way, one should define the concept. As already hinted at the very beginning, the term "second serfdom" (or "the second edition of serfdom") was introduced by one of the founders of Marxism - Friedrich Engels - during the 1880s (he used the term in his letters to K. Marx) ${ }^{7}$. Describing the situation in the Germany east of the Elbe after the peasant war in Germany (1524-1525) F. Engels mentioned large estates that were cultivated using forced labour (corvée) of serfs ${ }^{8}$. He also emphasized that corvée as well as rent in kind and in cash had increased significantly, although exactly corvée (labour rent) had been the most important ${ }^{9}$. What was that increased amount of corvée? According to F. Braudel, by the end of the $16^{\text {th }}$ century it had reached five days per week in Bohemia and six months per year in Slovenia ${ }^{10}$.

Besides, we would like to draw reader's attention to one more important element of the second serfdom. We mean those large estates cultivated by forced labour of serfs that were mentioned by F. Engels. It's quite a challenge to find a perfect English equivalent for proper translation

\footnotetext{
${ }^{6}$ Bideleux and Jeffries, 162 (reference to P. Longworth's book)

${ }^{7}$ F. Engelsas - K. Marksui, 1882 m. gruožio 15 d., in: F. Engelsas, Valstiečiu karas Vokietijoje (Vilnius: Valstybinè politinès ir mokslinès literatūros leidykla, 1962), 148 [148-149], F. Engelsas - K. Marksui, 1882 m. gruožio 16 d., in: Ibid., 150 [149-150]; for English translations of the relevant letters of F. Engels look: K. Marx and F. Engels, Collected Works (New York: International Publishers, 1992), vol. 46, 400, 403.

${ }^{8}$ F. Engelsas, „Dèl Prūsijos valstiečių istorijos. V. Volfo brošiūros ,Silezijos milijardas' ivvadas“, in: idem, Valstiečiu karas Vokietijoje..., 132-133; the publication of the original German text (Zur Geschichte der preußischen Bauern [Einleitung zu Wilhelm Wolffs Broschüre "Die schlesische Milliarde"]) available in internet: http://www.mlwerke.de/me/me21/me21_238.htm (accessed at 01/08/2012); the English translation of the text is published in K. Marx and F. Engels, Collected Works (New York: International Publishers, 1990), vol. 26 (under the circumstances it is impossible to specify exact pages since the volume is not available in Lithuania).

${ }^{9}$ F. Engelsas, "Dèl Prūsijos valstiečių istorijos", p. 134; the publication of the German text in internet: http://www.mlwerke.de/me/me21/me21_238.htm (accessed at 01/08/2012). 10 Braudel, F. Grammaire des civilisations, 434.
} 
of this kind of estate (a Polish equivalent is Folwark). I would like to propose the term manorial-serf system (which I found in the Polish historian Topolsky texts published in English).

So, if one wants to talk about the second serfdom at least three characteristics must be clearly distinguished:

1) serfdom; it is quite a complicated notion to define, since as much as I know historiography can not propose the final answer to this issue yet ${ }^{11}$. I'm not willing to get into intricate discussion here, all I intend to do is to propose conventional definition, i.e., to consider serfdom as personal subjugation of agricultural labourers to landlords, which usually took the form of land-binding.

2) corvée (or labour rent as used in Marxist terminology, i.e., compulsory serf labour) as a dominating form of exploitation of direct producers; an amount of corvée should be large enough, about the level mentioned by F. Braudel (i.e., five days per week or six months per year).

3) manorial-serf system (Folwark), i.e., landlord's estate cultivated by forced labour i.e., corvée.

In my opinion, one can claim that she deals with a case of the second serfdom only if all three characteristics are present in one society or another in a certain era.

So, there are three statements that we have to argue in this paper:

1. The second serfdom has spread in most of the countries of Central and Eastern Europe (from the Germany east the Elbe to the Balkans and Muscovy);

2. All occurrences of second serfdom (all around the whole region of Central and Eastern Europe) were based on manorial-serf (i.e., Folwark) economy, which in turn is necessarily based on forced labour of serfs;

3. The second serfdom was caused by increased demand for agricultural products (especially grain).

\section{Case comparison}

Here we should try to find the answers to the following questions:

1) do societies of Poland, the Grand Duchy of Lithuania and Moldova satisfy the criteria of the second serfdom in the $16^{\text {th }}$ (or the first

\footnotetext{
11 Look, e.g.: J. Jurginis, Baudžiavos ísigalëjimas Lietuvoje (Vilnius: Valstybinè politinès ir mokslinès literatūros leidykla, 1962), 10-15.
} 
half of the $17^{\text {th }}$ ) century?

2) is the influence of international trade and international labour division decisive to the socioeconomic development of the selected societies in the $16^{\text {th }}$ (or the first half of the $17^{\text {th }}$ ) century?

Since Poland is usually approached as a classic example of society of the second serfdom region, let us start from the Polish case. According to the famous Polish economic historian Jerzy Topolski, "of those countries where manorial-serf economy developed, Poland is the earliest, and her manors among the most dynamic" 12 . This process caused rapid changes in the statute of peasants. Their situation worsened: they were bound to the land, corvée increased significantly and it kept increasing until the $18^{\text {th }}$ century, inclusively ${ }^{13}$. The process of land-binding began in the middle of $14^{\text {th }}$ century (then some restrictions concerning leaving the land were introduced $)^{14}$ but it has been intensifying starting from the end of $15^{\text {th }}$ century and it was completed at the beginning of $16^{\text {th }}$ century (except for the Mazovia region where peasants lost their right to leave the land without landlord's permission in 1576)15. According to J. Topolski, "the growing foreign and domestic demand caused the increase in peasant labour obligations “16 By 1530, the amount of corvée had reached 2 days, by 1560 - 3 days, and by the $17^{\text {th }}$ century even 4 or 5 days per week for an average peasant farm ${ }^{17}$.

Besides, considering the dominating export product, Poland was also a classic case: it was exactly a grain-producing region and exporter to Western Europe during the $16^{\text {th }}-17^{\text {th }}$ centuries $^{18}$. On the other hand, one should keep in mind that even in Poland entire regions (like Western Poland) produced grain mostly not for foreign but for domestic market ${ }^{19}$. In general, as Lithuanian historian Darius Žiemelis soundly argued recently in his doctoral thesis, external trade of Poland did not surpass the internal

\footnotetext{
12 J. Topolski, "The Manorial-Serf Economy in Central and Eastern Europe in the 16th and 17th Centuries", Agricultural History 48, No. 3 (Jul., 1974), 350.

13 Look: S. Inglot (red.) Historia chłopów polskich (Warszawa: Ludowa spółdzielnia wydawnicza, 1970), t. 1, 310.

14 Look: Ibid., 248; H. Łowmiański, Początki Polski t. VI, 1 (Warszawa: Państwowe Wydawnictwo Naukowe, 1985), 572.

15 Look: Inglot, t. 1, 309-310.

16 Topolski, 350.

17 Look: Inglot, t. 1, s. 310.

18 Look: Topolski, 351.

19 Look: Ibid., 351.
} 
one. It means that even in Poland manors (manorial-serf systems) that produced for domestic market prevailed, and not otherwise. Therefore, influence of external trade was overestimated ${ }^{20}$.

In the Grand Duchy of Lithuania (GDL) peasants were bound to the land between the middle of $15^{\text {th }}$ century and the middle of $16^{\text {th }}$ (this process had completed earlier in private domains: already in the second half of $15^{\text {th }}$ century) ${ }^{21}$. An agrarian reform occurred in GDL, that was successfully implemented in the middle of $16^{\text {th }}$ century. After the reform, the corvée became the most important obligation of peasants on estates of Grand Duchy of Lithuania22. Just after the reform, corvée amounted to 2 days per week from the settled land measuring unit (valakas) ${ }^{23}$. The demand for corvée kept increasing. Therefore, the amount of corvée had reached even 6 days per week until the middle of $17^{\text {th }}$ century ${ }^{24}$.

According to D. Žiemelis, GDL was involved in international trade on a smaller scale compared to Poland (i.e., only sporadically, depending on accidental circumstances, for example, harvest conditions etc.) ${ }^{25}$. Besides, what is important to keep in mind, Lithuania had been supplying not grain but mostly hemp and flax to Western markets in the $16^{\text {th }}-17^{\text {th }}$ centuries ${ }^{26}$.

According to the Romanian sociologist-historian Henri H. Stahl's reconstruction, in Moldavia serfdom (i.e.,, first of all, peasant's binding to the land and then even a practice to sell serfs) was established between the middle of $16^{\text {th }}$ century and the first quarter of $17^{\text {th }}$ century ${ }^{27}$.

${ }^{20}$ D. Žiemelis, Abieju Tautu Respublikos socialinè ekonominè raida XVI-XVIII amžiuje: feodalizmas ar periferinis kapitalizmas? Istoriografine analizé. Daktaro disertacija. Humanitariniai mokslai, istorija (05H) (Vilnius: Vilniaus univeristetas, 2009), 138-139; compare: D. Žiemelis, Feudalism or Peripheral Capitalism. Socio-economic History of the Polish-Lithuanian Commonwealth in the 16th to 18th centuries (Saarbrücken, 2011), 36-38.

${ }^{21}$ Look: , E. Gudavičius, Lietuvos istorija, t. 1: Nuo seniausiu laiku iki 1569 metu. Pakartotinis leidimas (Vilnius: Lietuvos rašytojų sąungos leidykla, 2001), 575, compare: Jurginis, 300-301. 22 Look: Gudavičius, t. 1, 577.

${ }^{23}$ Look: Jurginis, 281, Gudavičius, t. 1, 577.

24 Look: Jurginis, 294-295.

${ }^{25}$ Look: Žiemelis 2009, 168.

${ }^{26}$ Look: Topolski, 351.

27 H. H. Stahl, Traditional Romanian village communities: the transition from the communal to the capitalist mode of production (Cambridge University Press, 1980), 172-175, 180-181, 184-185; compare: D. Mioc, H. Chircă and Ş. Ştefănescu, „L'évolution de la rente féodale en Valachie et en Moldavie du XIVeau XVIII siécle“, in: Nouvelles études d'histoire, XI congrès des sciences historiques (Stockholm, Bucarest), 1960, 229. 
According to the outstanding Moldavian medieval historian Pavel Sovetov, the particularities of Moldova's bio-productive economy's structure (with prevalence of animal breeding, viticulture, apiculture; grain harvesting is less developed than, for example, in Poland) determined very limited increase of corvée (labour rent) in Moldova in the $16^{\text {th }}-17^{\text {th }}$ centuries. This could be explained by a much lower demand for mandatory work, especially in case of animal breeding 28 . Based on the amount of corvée, P. Sovetov divides peasants of Moldova in two main categories. Most peasants (about 90\%) belong to the first category. The amount of corvée (labour rent) of peasants in the first category was very small (approximately 12 days per year) and was not determined precisely. This is because corvée was not their main obligation. Whereas peasants distributed to the second category (which was considerably smaller - only about $10 \%$ ) were obliged to the large amount of specialised corvée (labour rent) - 100-150 days a year (from a household). The latter amount of corvée (labour rent) is not far away from the level of the second serfdom region. On the other hand, the state taxes and obligations were significantly diminished for those peasants and this was an essential advantage in the context of Moldova in the second half of the 16th - 17th centuries ${ }^{29}$.

Moldova (as well as Wallachia) did not export cereals in large quantities, since it specialized as a livestock exporter (sheep, cattle, horses and swine $)^{30}$. However, according to H. H. Stahl, "the Romanian countries did not feel the effects as deeply as the Baltic countries" 31 . P. Sovetov, in essence, shares the opinion of H. H. Stahl. He states that under the Ottoman domination manors of Moldavian boyars did not manage to adjust to the international market as much as those in Eastern and Central Europe ${ }^{32}$. Nevertheless, opinions vary. According to Romanian scholars Florin Bonciu and Bogdan Murgescu, greater need for cash and growing demand from both European and Ottoman markets determined the expansion of export activities in the $16^{\text {th }}$ century. The aforementioned scholars claimed that Moldova kept obtaining important revenues from international trade,

\footnotetext{
28 П. В. Советов, Развитие феодализма и крестьяне Молдавии. (Очерки истории ренты 6 XVI - начале XVIII в.) (Кишинёв: Штиинца, 1980), 276-277.

${ }^{29}$ Советов, 277-278; also compare another opinion which is not so well sound: Mioc, Chircă and Ştefănescu, 236-240.

${ }^{30}$ Look: Stahl, 177, Topolski, 351.

31 Ibid., 177.

32 Советов, 276-277.
} 
especially taking advantage of economic links to European and Ottoman markets ${ }^{33}$.

\section{Generalization}

Let's summarize all three cases. I suppose the best way to do it is to put essential data into the following table:

Table 1: To what extent do selected cases satisfy the second serfdom criteria?

Table

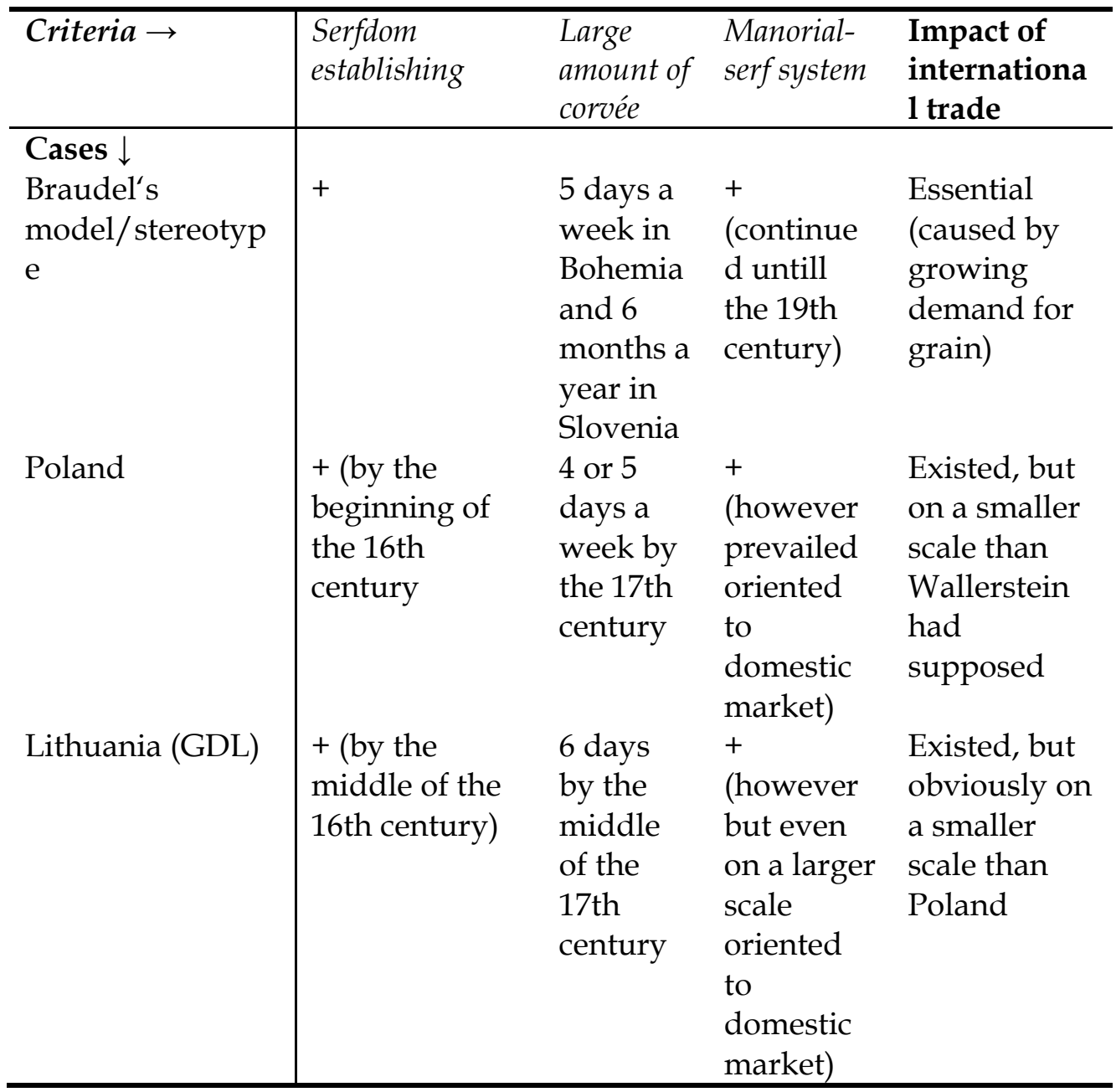

${ }^{33}$ F. Bonciu, B. Murgescu, "The World-Approach and Romanian Economic History“", Revue Roumaine d'histoire (Bucureşti), 29, № 3-4 (1990): 278-279. 


\begin{tabular}{l|llll}
\hline Moldova & $\begin{array}{l}\text { + (by the end } \\
\text { of the 16th }\end{array}$ & 12 days a & - (at least & Existed, but \\
century & on a larger & should not \\
approximately & of serfs), & scale) & be \\
exaggerated & $100-150$ & \\
days a & \\
& year & \\
& (minorit & \\
& y - $10 \%-$ & \\
& of serfs) & \\
& &
\end{tabular}

Now let us generalize based on the table shown above. In all three cases serfdom (as defined in the introduction section) was established before 1600. Concerning the amount of corvée that define the second serfdom model, only Poland and Lithuania satisfy this criterion. One can not state the same in the case of Moldova. The same can be stated for the case of manorial-serf system, because those two criteria are directly connected since, as defined in the introduction part, manorial-serf system as such must be based on forced labour of serfs. It is important to keep in mind that my thesis gets confirmation in Moldavian historiography.

Concerning the impact of international trade (especially the demand for agricultural products on Western Europe markets), one can not deny existence of the impact as such, but still it should not be overestimated.

\section{Conclusions}

The following conclusions could be drawn:

1. The second serfdom, as one can define it according to a classic model, had not spread all over countries in Central and Eastern Europe (especially as F. Braudel defined it: from the Germany east the Elbe to the Balkans and Muscovy).

2. The regime of serfdom established in Moldova until 1600 does not correspond with the classic model. In this case one can talk only about another type of second serfdom which differs from that of Eastern Germany as well as from Central Europe.

3. It would be a gross simplification to claim that second serfdom phenomenon was caused exclusively by external reasons. Internal causes are not less but probably even more decisive, at least in some cases. On the other hand, the impact of international trade should not be denied. 
However one should not be "enchanted" by the lopsided explanation of I. Wallerstein. As the work of Darius Žiemelis has showed recently, statements of world-system approach toward certain societies are worth of critical scrutiny and reconsideration.

\section{References:}

\section{A. Books and articles:}

Bideleux, R., and I. Jeffries. A History of Eastern Europe. Crisis and Change. Second Edition. London, New York: Routledge, 2007.

Bonciu, F. and B. Murgescu, "The World-Approach and Romanian Economic History“, Revue Roumaine d'histoire 29, № 3-4 (1990).

Braudel, F., A History of Civilizations. Penguin Books, 1993 [Grammaire des civilisations. Paris: Flammarion, 1993].

Engelsas, F. Valstiečiu karas Vokietijoje. Vilnius: Valstybinè politinès ir mokslinès literatūros leidykla, 1962.

Gudavičius, E. Lietuvos istorija, t. 1: Nuo seniausiu laiku iki 1569 metu. Pakartotinis leidimas. Vilnius: Lietuvos rašytojų sąjungos leidykla, 2001.

Inglot, S. red. Historia chłopów polskich. Warszawa: Ludowa spółdzielnia wydawnicza, 1970, t. 1.

Jurginis, J. Baudžiavos ịsigalejimas Lietuvoje. Vilnius: Valstybinè politinès ir mokslinès literatūros leidykla, 1962.

Łowmiański, H. Początki Polski t. VI, 1, Warszawa: Państwowe Wydawnictwo Naukowe, 1985.

Marx, K., F. Engels, Collected Works. New York: International Publishers, 1990, vol. 26.

Marx, K., F. Engels, Collected Works. New York: International Publishers, 1992, vol. 46.

Mioc, D., H. Chircă, and Ş. Ştefănescu. „L'évolution de la rente féodale en Valachie et en Moldavie du XIVeau XVIIIe siècle." in: Nouvelles études d'histoire, XI congrès des sciences historiques. Stockholm, Bucarest, 1960.

Советов, П. В. Разбитие феодализма и крестьяне Молдавии. (Очерки истории ренты В XVI - начале XVIII в.). Кишинёв: Штиинца, 1980.

Stahl, H. H. Traditional Romanian village communities: the transition from the communal to the capitalist mode of production. Cambridge University Press, 1980. 
Szücs, J. "The three Historical Regions of Europe", Acta Historica Academiae Scientiarum Hungaricae 29, no. 2-4 (1983).

Topolski, J. "The Manorial-Serf Economy in Central and Eastern Europe in the 16th and 17th Centuries", in: Agricultural History, vol. 48, No. 3 (Jul., 1974).

Žiemelis, D. Abieju Tautu Respublikos socialinè ekonomine raida XVI-XVIII amžiuje: feodalizmas ar periferinis kapitalizmas? Istoriografine analizé. Daktaro disertacija. Humanitariniai mokslai, istorija $(05 \mathrm{H})$. Vilnius: Vilniaus univeristetas, 2009.

Žiemelis, D. Feudalism or Peripheral Capitalism. Socio-economic History of the Polish-Lithuanian Commonwealth in the 16th to 18th centuries. Saarbrücken, 2011.

\section{B. Web postings:}

Engels, F., Zur Geschichte der preußischen Bauern [Einleitung zu Wilhelm Wolffs Broschüre "Die schlesische Milliarde"]) available in internet: http://www.mlwerke.de/me/me21/me21_238.htm (accessed at 01/08/2012). 